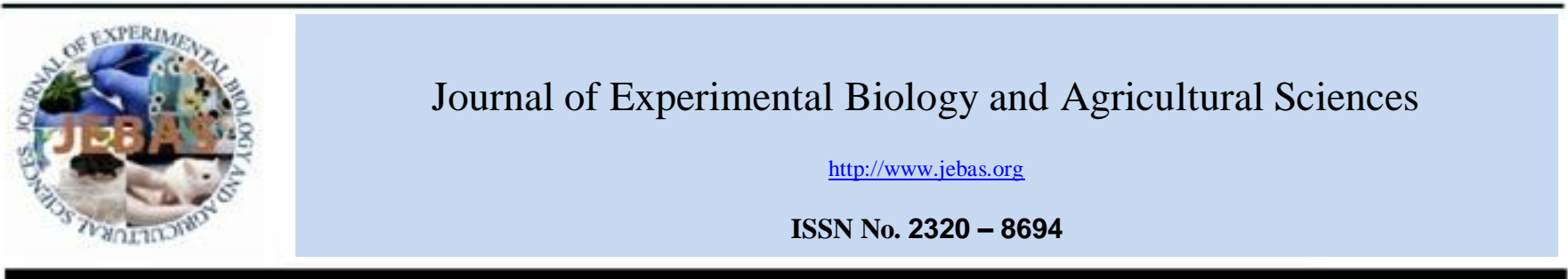

\title{
SUSCEPTIBILITY OF COTTON LEAFHOPPER Jacobiella facialis (HEMIPTERA: CICADELLIDAE) TO PRINCIPAL CHEMICAL FAMILIES: IMPLICATIONS FOR COTTON PEST MANAGEMENT IN CÔTE D'IVOIRE
}

\author{
Pitou Woklin Euloge KONE ${ }^{1,2 *}$, Gouzou Juste Roland DIDI ${ }^{1,2}$, Germain Elisabeth Cynthia OCHOU ${ }^{1,2}$, \\ Malanno KOUAKOU ${ }^{2}$, Kouadio Kra Norbert BINI ${ }^{2}$, Dagnogo MAMADOU ${ }^{1}$, \\ Ochou Germain OCHOU ${ }^{2}$
}

\footnotetext{
${ }^{1}$ University Nangui Abrogoua, Laboratory of Animal Cytology and Biology, 02 BP 801 Abidjan 02, Côte d'Ivoire.

${ }^{2}$ National Center of Agronomic Research, Cotton Research Station, Laboratory of Entomology, 01 BP 633 Bouaké 01, Côte d'Ivoire.
}

Received - July 11, 2018; Revision - August 10, 2018; Accepted - September 14, 2018

Available Online - October 5, 2018

DOI: http://dx.doi.org/10.18006/2018.6(5).774.781

\section{KEYWORDS \\ Jacobiella facialis \\ Active ingredients \\ Protection of cotton \\ Pyrethroïds \\ Côte d'Ivoire}

\section{* Corresponding author}

E-mail: eulogepitou@gmail.com (Pitou Woklin Euloge KONE)

Peer review under responsibility of Journal of Experimental Biology and Agricultural Sciences.

Production and Hosting by Horizon Publisher India [HPI] (http://www.horizonpublisherindia.in/).

All rights reserved.

\begin{abstract}
Jacobiella facialis is a sucking insect pest of cotton in Côte d'Ivoire. Heavy infestations on cotton resulted in shedding of leaves, squares, young bolls and subsequently lead to significant yield losses. In recent years, attacks of the jassid remain persistent throughout the entire crop cycle despite insecticide treatments. Susceptibility tests of ten (10) active ingredients (chlorpyrifos-ethyl, profenofos, acetamiprid, imidacloprid, alpha-cypermethrin, lambdacyhalothrin, spinoteram, sulfoxaflor, spinosad and chlorantraniliprole) were performed against pest populations collected in Bouaké by leaf-dip method $n^{\circ} 15$ proposed by Insecticide Resistance Action Commitee (IRAC 15, version 3). Lethal concentrations $\mathrm{LC}_{50}$ and $\mathrm{LC}_{90}$ were determined for all active ingredients. To compare susceptibility between different field strains, discriminate concentrations $\left(\mathrm{LC}_{90}\right)$ for the most toxic active ingredients were tested by the same method on jassid populations from five localities (Korhogo, Boundiali, Ferké, Ouangolo and Niakara). Five active ingredients, chlorpyrifos-ethyl, profenofos, acetamiprid, alpha-cypermethrin and imidacloprid, with respective lethal concentrations $\left(\mathrm{LC}_{50}\right)$ of $0.0012,0.011,0.024,0.057,0.070 \mathrm{mg} / \mathrm{ml}$, were the most toxic to jassid, while spinosad and chlorantraniliprole were the least toxic as $\mathrm{LC}_{50}$ values were $1.616 \mathrm{mg} / \mathrm{ml}$ and 5.4 $\mathrm{mg} / \mathrm{ml}$ respectively. Data collected on discriminate concentrations $\left(\mathrm{LC}_{90}\right)$ for four active ingredients did not revealed any significant difference between the susceptibility levels of jassid strains. However, it was noted that survival rates were consistently high in strain collected from Boundiali and Korhogo, indicating low heterogeneity within some field populations. The results have provided important information on active ingredients to consider when developing pest management programs.
\end{abstract}

All the article published by Journal of Experimental Biology and Agricultural Sciences is licensed under a Creative Commons Attribution-NonCommercial 4.0 International License Based on a work at www.jebas.org.

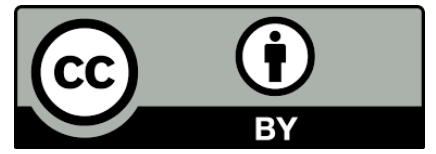




\section{Introduction}

Cotton is a major commercial crop grown in the Center and Northern areas of Côte d'Ivoire. It contributes to social and economic development of the populations living in these parts of the country (Koffi, 2013). Cotton crop is however subject to many constraints which deteriorate its production and fall of income for farmers. Cotton suffers from insect pest attacks throughout its growing season (Gangadhar et al., 2007). Indeed, cotton parasitism in Côte d'Ivoire is particularly diversified by comprising bollworm complex (Helicoverpa armigera, Thaumatotibia leucotreta, Pectinophora gossypiella) and sucking pests (Aphis gossypii, Bemisia tabaci, Jacobiella facialis) (Vaissayre et al., 1995; Ochou \& Martin, 2002; Ochou, 2011).

Among the various strategies adopted by farmers to manage pest damage, insecticides are the first line of defense. The repeated use of chemical formulations for crop protection can however lead to several risks. Among many other risks, development of insecticides resistant in pest populations is most common one. For instance, in Côte d'Ivoire, the massive and repeated usage of pyrethroïds has led to the selection of resistant populations of Helicoverpa armigera against this family of insecticides (Martin et al., 2000). Consequently, a strategy of management and prevention of resistance against pyrethroïd has been developed since 1998 to deal with this major pest (Ochou \& Martin, 2002; Djihinto et al., 2016). It aims to reduce the use of pyrethroïd by selecting their chemical alternatives (benzoylurea, diamides, organophosphorus, avermectines, etc.) to ensure part of the foliar treatments.

Despite the successful adoption of this strategy of protection, a number of previously minor pests caused increasing damage to cotton plants over the past 5 years, thus becoming more important pest. A large number of cotton growers are complaining about the persistence of severe infestations of leafhoppers J. facialis causing shedding of squares, young bolls, and leading subsequently to significant yield losses. In fact, jassid outbreaks occur throughout the crop production cycle. Damages are increasingly noticeable years after years (Koné et al., 2017).

With regard to the recent pest status, regular monitoring of its susceptibility to commonly used insecticides is necessary. The present study aimed to determine the susceptibility of jassid (J. facialis) against major active insecticides family in order to ensure judicious selection of insecticides for intensive management of jassid (J.facialis) in Côte d'Ivoire.

\section{Materials and Methods}

\subsection{Study area}

The study on susceptibility of $J$. facialis to various insecticides was carried out at the Cotton Entomology laboratory located in Bouaké $\left(7^{\circ} 67^{\prime} \mathrm{N},-5^{\circ} 09^{\prime} \mathrm{W}\right)$. The response of $J$. facialis after exposing to discriminate concentrations was undertaken in five localities within the cotton growing area (Figure 1), precisely in Korhogo $\left(9^{\circ} 27^{\prime} \mathrm{N},-5^{\circ} 37^{\prime} \mathrm{W}\right)$, Boundiali ( $\left.9^{\circ} 52^{\prime} \mathrm{N},-6^{\circ} 47^{\prime} \mathrm{W}\right)$, Ferké $\left(9^{\circ} 6^{\prime} \mathrm{N},-5^{\circ} 2^{\prime} \mathrm{W}\right)$, Ouangolo $\left(9^{\circ} 97^{\prime} \mathrm{N},-5,15^{\prime} \mathrm{W}\right)$ and Niakara $\left(8^{\circ} 67^{\prime} \mathrm{N},-5^{\circ} 28^{\prime} \mathrm{W}\right)$.

\subsection{Materials}

\subsubsection{Target pest insect}

This study was performed on adults Jacobiella facialis Jacobi, 1912 (Cicadellidae), a sap sucking pest of cotton which lives underside of leaves. These are small in size, ranging in colour from green, through yellow-green to brown. Severe infestation may cause plants to shed squares and small bolls although this rarely happens. Larger bolls may turn soft and spongy and fail to mature (Godfrey et al., 2008; Madar \& Katti, 2010; Selvaraj et al., 2011).

\subsubsection{Jassid collections}

The jassid collection was performed on cotton plants in farmers' field and all stages of insect were collected. The captured insects were collected in a cage having young cotton plant and covered with muslin clothes in order to bring them back to laboratory according to the method of Ahmad et al. (1999).

\subsubsection{Insecticidal formulations}

Ten (10) active ingredients of commercial formulations which were used for the bioassays are presented in Table 1. They belong to different chemical families and are from various sources.

\subsection{Methods}

Bioassays were performed on J. facialis adults, collected from field and reared under laboratory conditions up to the $1^{\text {st }}$ generation, using leaf-dip method $\mathrm{n}^{\circ} 15$ proposed by Insecticide Resistance Action Committee (IRAC 15, version 3). Several insecticidal concentrations were prepared by diluting these formulations in distilled water. Cotton leaf disc (55 mm diameter) were cut and dipped with gentle agitation into test solution for 20 seconds or in distilled water to serve as a control. These leaf discs allowed to surface-dry on an absorbent paper. Then, these were positioned on agarose gel $(6 \mathrm{~g} / \mathrm{l})$ cast at the bottom of petri dish with upper surface of the leaf against gel. Ten (10) adults of 


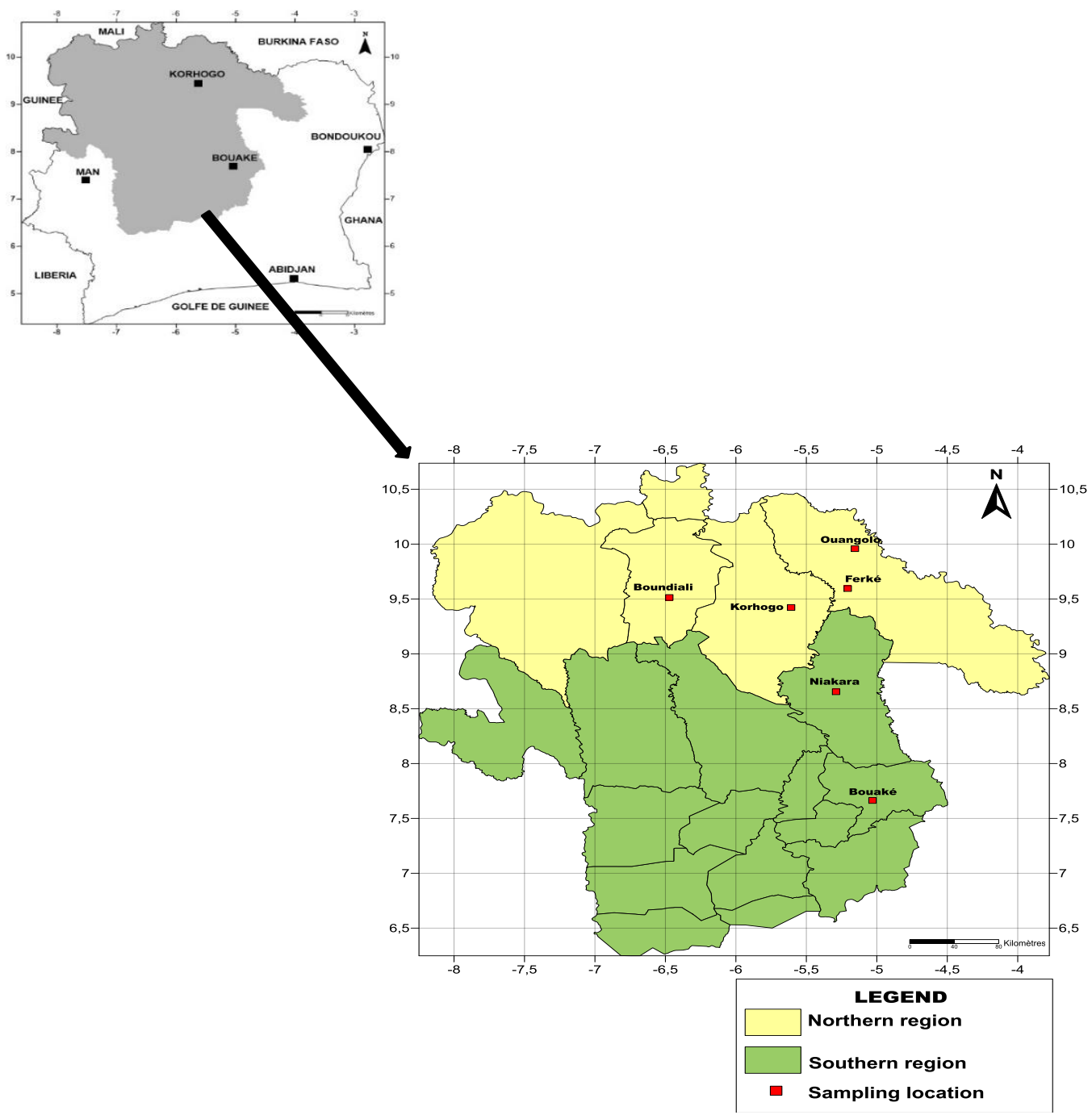

Figure 1 Area of study showing sample locations of Jacobiella facialis

jassids were removed from the rearing cage and were anesthetized with carbon dioxide $\left(\mathrm{CO}_{2}\right)$ for a short time. Then they are placed on underside of the treated leaf and petri dish was closed with an airy (ventilated) lid. After jassids were recovered from anesthesia, each petri dish was turned over so that the lid was down. Three repetitions were performed for each concentration and petri dishes were stored at $26 \pm 2{ }^{\circ} \mathrm{C}$ temperature, $55.2 \pm 13 \%$ relative humidity and $24 \mathrm{~h}$ for photoperiod (12h of light and $12 \mathrm{~h}$ of darkness). Jassid mortality in each dish was recorded after $48 \mathrm{~h}$ exposure to determine $\mathrm{LC}_{50}$ and $\mathrm{LC}_{90}$ values. Moribund individuals, unable to promptly make a movement, were considered dead.

The $\mathrm{LC}_{90}$ concentration of 4 active ingredients (chlorpyrifos-ethyl, profenofos, alpha-cypermethrin and acetamiprid) was used as a discriminate concentration to diagnose susceptibility of 5 strains of jassid from Korhogo, Boundiali, Ferké, Ouangolo and Niakara. Distilled water served as control for all toxicology tests.

\subsection{Data analysis}

The mortality data were corrected by the formula of Abbott (1925) and analyzed by probit analysis (Finney, 1971) using the software Win DL version 2.0 from CIRAD to determine lethal concentration (LC) values. Data on the susceptibility of different strains of jassid were expressed as percent survivors. The error bars on the histograms were represented from the standard deviation values attached to each of these rates. The analysis of variance (ANOVA) was calculated with SPSS software version 20. Differences among treatment means were tested with Duncan multiple range test at 5\% significant level.

Journal of Experimental Biology and Agricultural Sciences http://www.jebas.org 
Table 1 Insecticidal formulations tested for bioassays

\begin{tabular}{|c|c|c|c|c|c|}
\hline Chemical family & Active ingredient & Trade name & Content & Dose of usage & Manufacturer \\
\hline \multirow[b]{2}{*}{ Neonicotinoïds } & Acetamiprid & Assail $30 \mathrm{SG}$ & $16 \mathrm{~g} / \mathrm{l}$ & $1 \mathrm{l} / \mathrm{ha}$ & Dow AgroSciences \\
\hline & Imidacloprid & Caotop $30 \mathrm{SC}$ & $30 \mathrm{~g} / 1$ & 1 1/ha & $\begin{array}{c}\text { Ningbo Sega Chemical Company } \\
\text { / N.S.G.M.C }\end{array}$ \\
\hline \multirow{2}{*}{ Organophosphorus } & Chlorpyrifos-ethyl & Pyriforce 480 EC & $480 \mathrm{~g} / 1$ & 1 à 2 1/ha & STEPC / LDC \\
\hline & Profenofos & Curacron 720 EC & $720 \mathrm{~g} / 1$ & 1 1/ha & Syngenta / RMG \\
\hline \multirow{2}{*}{ Pyrethroids } & Lambda-cyhalothrin & Karate zeon & $100 \mathrm{~g} / \mathrm{l}$ & _ & Dow AgroSciences \\
\hline & Alpha-cypermethrin & Fastac SC & $100 \mathrm{~g} / \mathrm{l}$ & - & Dow AgroSciences \\
\hline \multirow{2}{*}{ Spinosyns } & Spinosad & GF-976 SC & $480 \mathrm{~g} / \mathrm{l}$ & - & Dow AgroSciences \\
\hline & Spinetoram & GF-1567 SC & $480 \mathrm{~g} / \mathrm{l}$ & - & Dow AgroSciences \\
\hline Sulfoximines & Sulfoxaflor & GF-2032 SC & $240 \mathrm{~g} / 1$ & - & Dow AgroSciences \\
\hline Diamides & Chlorantraniliprole & Coragen SC & $200 \mathrm{~g} / 1$ & - & Dupont \\
\hline
\end{tabular}

Table 2 Susceptibility of Jacobiella facialis population from Bouaké to ten active ingredients

\begin{tabular}{|c|c|c|c|c|c|c|c|c|}
\hline Chemical family & Active ingredient & $\mathrm{n}$ & $\mathrm{LC}_{50} \pm \mathrm{SD}$ & $95 \% \mathrm{CL}$ & $\chi^{2}$ & df & Slope & $\mathrm{LC}_{90} \pm \mathrm{SD}$ \\
\hline \multirow{2}{*}{ Organophosphorus } & Chlorpyrifos-ethyl & 270 & $0.0012 \pm 0.0002$ & $0.0003-0.003$ & 5.99 & 7 & 0.686 & $0.090 \pm 0.003$ \\
\hline & Profenofos & 150 & $0.011 \pm 0.0038$ & $0.0005-0.42$ & 1.722 & 3 & 0.801 & $0.47 \pm 0.025$ \\
\hline \multirow{2}{*}{ Neonicotinoïds } & Acetamiprid & 300 & $0.024 \pm 0.0030$ & $0.0029-0.07$ & 1.286 & 8 & 0.668 & $1.98 \pm 0.032$ \\
\hline & Imidacloprid & 300 & $0.070 \pm 0.0022$ & $0.00501-0.04$ & 6.321 & 7 & 0.649 & $1.66 \pm 0.029$ \\
\hline \multirow{2}{*}{ Pyrethroïds } & Alpha-cypermethrin & 300 & $0.057 \pm 0.0044$ & $0.0018-0.26$ & 8.429 & 8 & 0.491 & $23.09 \pm 0.41$ \\
\hline & Lambda-cyhalothrin & 210 & $0.132 \pm 0.024$ & $0.021-0.343$ & 3.365 & 5 & 0.746 & $6.93 \pm 0.36$ \\
\hline \multirow{2}{*}{ Sulfoximines } & Spinoteram & 240 & $0.119 \pm 0.033$ & $0.012-0.391$ & 6.056 & 5 & 0.673 & $9.59 \pm 0.30$ \\
\hline & Sulfoxaflor & 180 & $0.157 \pm 0.019$ & $0.049-0.3328$ & 3.364 & 4 & 0.964 & $3.35 \pm 0.26$ \\
\hline Spinosyns & Spinosad & 240 & $1.616 \pm 0.023$ & $0.332-3.923$ & 8.415 & 5 & 0.790 & $67.66 \pm 0.30$ \\
\hline Diamides & Chlorantraniliprole & 180 & $5.4 \pm 0.020$ & $0.761-10.97$ & 0.589 & 4 & 1.268 & $55.34 \pm 0.23$ \\
\hline
\end{tabular}

n: number of tested insect $\quad 95 \%$ CL: 95\% Confidence limits $\quad \chi^{2}$ : Chi2 $\quad$ df: degree of freedom

\section{Results}

\subsection{Susceptibility of $J$. facialis against used active ingredients}

Efficacy of selected insecticides (10) was evaluated on the basis of jassids mortality. It was reported that all selected insecticides have significant effect on jassids mortality as compared to the control. $\mathrm{LC}_{50}$ value $(\mathrm{mg} / \mathrm{ml})$ of insecticides for jassids from Bouake varied with the types of tested actives ingredients as shown in table 2. Among the chemical bioassay, chlorpyrifosethyl $(0.0012 \mathrm{mg} / \mathrm{ml})$ and profenofos $(0.011 \mathrm{mg} / \mathrm{ml})$ registered less $\mathrm{LC}_{50}$ values while this value was reported highest for the 
spinosad $(1.616 \mathrm{mg} / \mathrm{ml})$ and chlorantraniliprole $(5.4 \mathrm{mg} / \mathrm{ml}) . \mathrm{LC}_{50}$ values of acetamiprid, alpha-cypermethrin, imidacloprid, spinetoram, lambda-cyhalothrin and sulfoxaflor against jassids populations were reported $0.024,0.057,0.070,0.119,0.132$ and $0.157 \mathrm{mg} / \mathrm{ml}$ respectively.

\subsection{Susceptibility of different $J$. facialis strains against used insecticides}

In order to assess their susceptibility level to four active ingredients, six strains of $J$. facialis were tested using discriminate concentrations. Survival rates of the tested jassid batches varied according to active ingredients and localities. Susceptibility of various $J$. facialis strains against used active ingredients has been shown in Figure 2.

At $1.98 \mathrm{mg} / \mathrm{ml}$ acetamiprid, survival rates varied from 3.33\% (Bouaké, Ouangolo, Niakara) to $13.33 \%$ (Boundiali) while at the same concentration Korhogo and Ferké strains strain have $6.67 \%$ survival (Figure 2a). Further, it was reported that the survival rate for Boundiali strain is 4 fold higher than those of Bouaké, Ouangolo and Niakara strains.
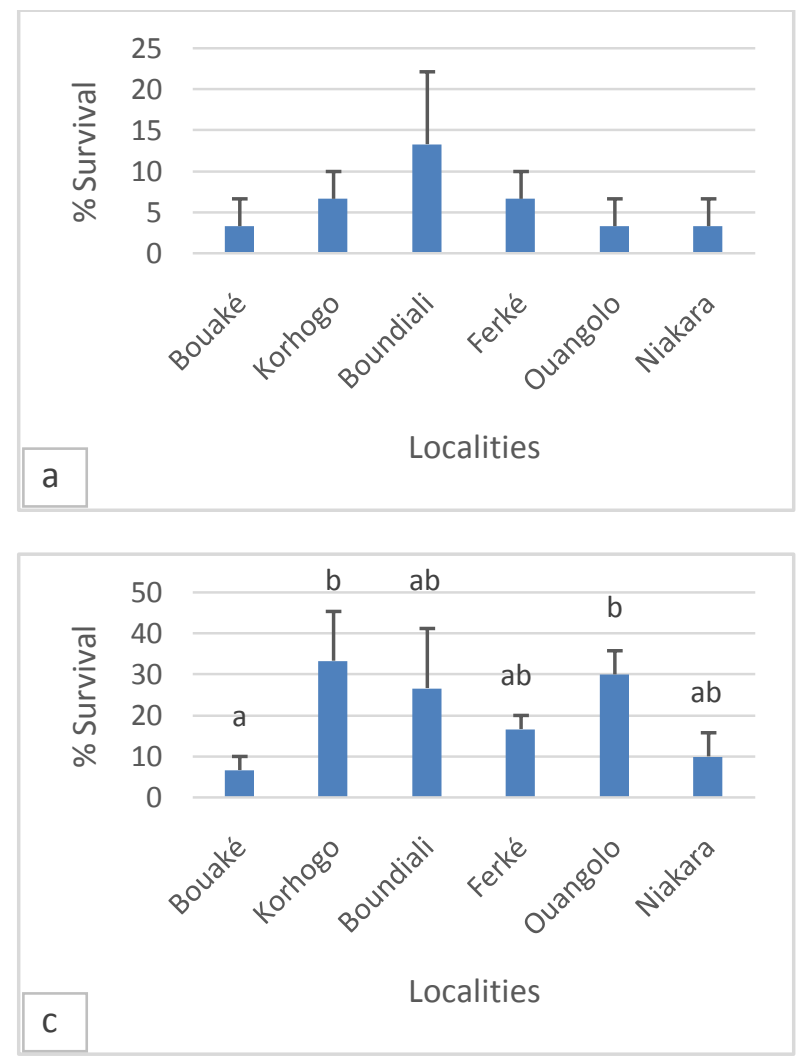

Figure 2 Jacobiella facialis strains survival percentage once exposed to active ingredients
a) Acetamiprid
b) Alpha-cypermethrin
c) Chlorpyrifos-ethyl
d) Profenofos

Survival rates against profenofos insecticides at $0.47 \mathrm{mg} / \mathrm{ml}$ varied between $10 \%$ (Bouaké, Ferké, Ouangolo, Niakara) to $26.67 \%$ (Boundiali). For Korhogo this rate was $23.33 \%$ (Figure 2b). However, survival rates for Boundiali and Korhogo strains were 2 fold higher than those obtained for other strains.

In case of chlorpyrifos-ethyl, survival rates were reported between $6.67 \%$ (Bouaké) to $33.33 \%$ (Korhogo) at $0.09 \mathrm{mg} / \mathrm{ml}$ concentration. For Niakara, Ferké, Boundiali and Ouangolo strains, the rate of surviving jassids were 10, 16.67, 26.67 and 30 percent respectively. Further, survival rates for Korhogo and Ouangolo strains were more than 4 fold higher than the Bouaké strain (Figure 2c).

Survival rates to alpha-cypermethrin at $23.09 \mathrm{mg} / \mathrm{ml}$ were reported $6.67 \%$ for Boundiali, Bouaké and Ferké. While in case of Niakara and Korhogo, the survival rates were $13.33 \%$. Further, in case of Korhogo and Niakara strains, survival rate were nearly two fold higher than the survival rates of Bouaké, Boundiali and Ferké strains and this difference was significantly differ (Figure $2 d)$. Data collected on discriminate concentrations $\left(\mathrm{LC}_{90}\right)$ for four (4) active ingredients did not reveal any significant difference
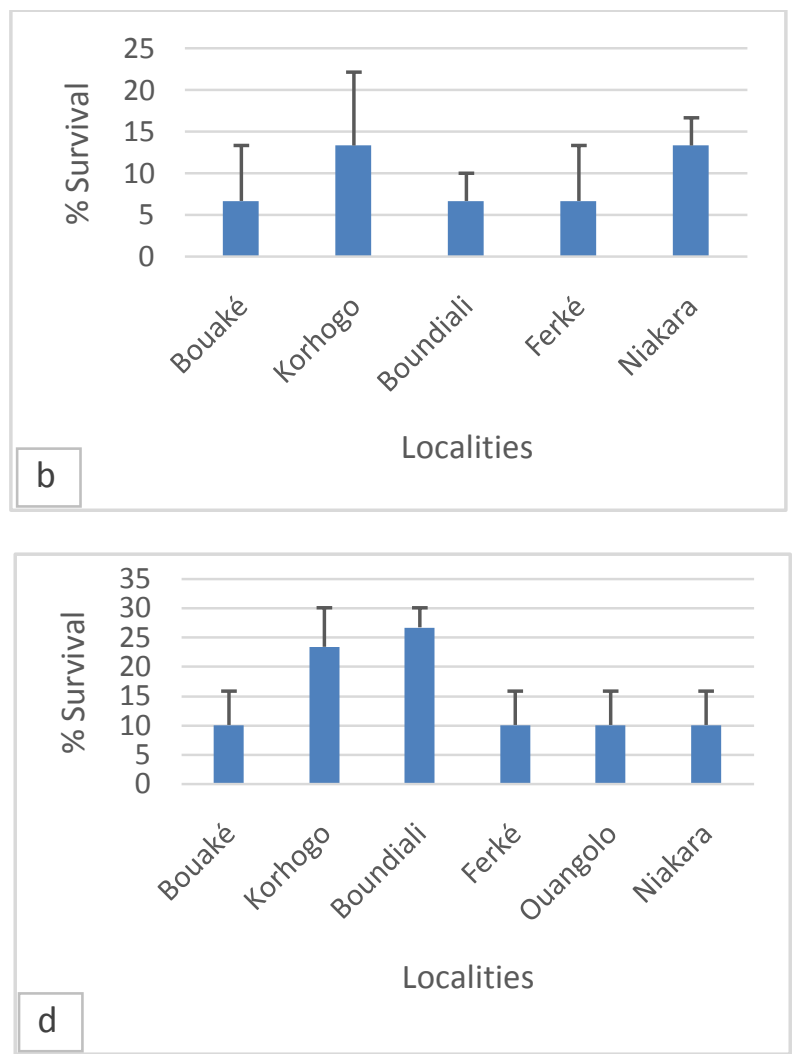

Journal of Experimental Biology and Agricultural Sciences http://www.jebas.org 
between the susceptibility levels of jassid strains, except for chlorpyrifos-ethyl

\section{Discussion}

Jassid is a sap sucking insect of many crops throughout the world. Recently, it became most important and emergent pest of cotton in Côte d'Ivoire (Koné et al., 2017). However, there are little information on the susceptibility of this pest against used insecticides for crop protection because studies on J. facialis are limited in Côte d'Ivoire and in West Africa region. So, regular monitoring of pest susceptibility to commonly used pesticides is necessary to take decision for ensure prudent selection of insecticides for effective pest management programs. In the present study, some insecticides such as pyrethroïds, organophosphorus, neonicotinoids which are widely used in Côte d'Ivoire for the management of various cotton pests including sucking pests over the years (Ochou \& Martin, 2002) and some new insecticides which belong to new chemical families of insecticides (spinosynes, sulfoximines, diamides and oxadiazines) have been assessed as an alternatives of the commonly used pesticides.

Variable susceptibility levels were detected among populations of $J$. facialis to different insecticides. The reduction in the size of jassid population indicated that all tested active ingredients were effective against jassid. Among these tested insecticides, chlorpyrifos-ethyl had highest toxic effect and this was followed by profenofos, acetamiprid, alpha-cypermethrin, imidacloprid, spinoteram, lambda-cyhalothrin, sulfoxaflor, spinosad and chlorantraniliprole.

Furthermore, among the tested insecticides, lowest $\mathrm{LC}_{50}$ values were reported from the chlorpyrifos-ethyl and profenofos and these two belongs to the organophosphorus family which act as non-systemic insecticide and work with contact, stomach and respiratory action. This family of insecticides inhibited acetylcholine esterase, an enzyme responsible of acetylcholine degradation involved in the excitatory neurotransmition. The residence time of acetylcholine at synapses is so prolonged by acetylcholine esterase inhibition, resulting in hyper-excitation and eventual death (Elersek \& Filipic, 2011; Kostic et al., 2015). The concentrations of organophosphorous could be used as a choice of jassids control. Concerning chlorpyrifos-ethyl, the differences observed in survival rates between jassid strains showed a high sensitivity of the strain from Bouaké compared to those from Korhogo and Ouangolo, while strains from Boundiali, Ferké and Niakara showed an intermediate susceptibility level.

Acetamiprid and imidacloprid performed appreciable activity on jassid populations. These molecules belongs to the family of neonicotinoids which strongly bind to nicotinic acetylcholine receptors in the central nervous system of insects and causing nervous stimulation at low concentrations, but receptor blockage, paralysis and death at higher concentrations (Tomizawa \& Casida, 2005; Kundoo et al., 2018). Similar result was also observed by Gopal \& Tarikul (2014) those who reported that plants treated with imidacloprid have significantly less jassid populations.

Chlorantraniliprole was found to be the least toxic pesticide to the leafhopper with a higher $\mathrm{LC}_{50}$ value. This can be due to the fact that chlorantraniliprole is a molecule whose effectiveness is mainly proven on Lepidopteran (Lamotte \& Fleury, 2012).

All concentrations tested under laboratory conditions should be tested for farm-based studies to confirm their effectiveness because in farm conditions, the environment is different from natural environment. As indicated by Koffi et al. (1998) bioassays under field conditions make it possible to judge the operational effectiveness of the tested insecticide, thus allowing a more realistic approach of the effectiveness of an insecticide in the field.

With respect to different dilutions of active ingredients, jassid strains from Bouaké, Korhogo, Boundiali, Ferké, Ouangolo and Niakara did not revealed any statistical differences in the survival rates, except for chlorpyrifos-ethyl. These results revealed that different locations leafhopper populations did not affect significantly from the used insecticides and showed at part susceptibility against acetamiprid, alpha-cypermethrin and profenofos. In fact, cotton growers in all these region seriously used the recommendation of protection program established since 1998. Cotton protection follows calendar treatments which recommend restricted use of pyrethroïds (Ochou \& Martin 2002; Martin et al., 2005).

Although pooled data analysis suggested that the six jassid strains have a overall similar susceptibility against the used insecticides. After this also a general trend comes out which suggested that strains from Boundiali and Korhogo had higher survival rates as compared to the rest four strains (Bouaké, Niakara, Ferké and Ouangolo). The present findings are similar to that of Wei et al. (2015), those who reported that all four strains of Empoasca vitis has similar susceptibility against acetamiprid, imidacloprid, bifenthrin and chlorfenapyr, but there was a trend that two strains differed in their susceptibility level. This observation may be due to several factors, among which, one factor might be a relatively higher tolerance of both strains to active ingredients associated to agricultural practices. Another factor could be a possible heterogeneity within the population of both strains. However one should note that the number of populations evaluated in this study was very limited. Future studies with a much wider coverage are required to depict general trends. 


\section{Conclusion}

The results of present study not only provide potency information of individual insecticides against this economically important insect but also provide some background information for further evaluation related to the susceptibility development in leafhopper in the cotton growing area of Côte d'Ivoire. The analysis of $\mathrm{LC}_{50}$ values has revealed different susceptibility levels of the tested insecticides. These results could serve as a useful guide for developing $J$. facialis IPM programs to ease the pressure of insecticide resistance. Future studies in field conditions with much wider coverage are required to depict general trends. The susceptibility level of acetamiprid, profenofos and alphacypermethrin is found approximately same for all jassid strains but detail field study required to established obtained facts.

\section{Conflict of interest}

All the authors declare that there is no conflict of interest.

\section{References}

Abbott WS (1925) A method of computing of effectiveness of an insecticide. Journal of Economic Entomology 18: 256-267.

Ahmad M, Arif MI, Ahmad Z (1999) Detection of resistance to pyrethroïds in field populations of cotton jassid (Homoptera: Cicadellidae) from Pakistan. Journal of Economic Entomology 92: 1246-1250.

Djihinto CA, Affokpon A, Dannon E, Bonni G (2016). Le profenofos, un alternatif à l'endosulfan en culture cotonnière au Bénin. International Journal of Biological and Chemical Sciences 10 : 175-183. DOI :http://dx.doi.org/10.4314/ijbcs.v10i1.12.

Elersek T, Filipic M (2011) Organophosphorous Pesticides Mechanisms of Their Toxicity. In: Pesticides - The Impacts of Pesticides Exposure. In Tech Europe: 243-260.

Finney DJ (1971) Probit Analysis. Third edition Cambridge. United Kingdom: Cambridge University Press Pp. 333.

Gangadhar B, Dahiya KK, Takar BL (2007) Evaluation of different biopesticides against cotton bollworms. Journal of Cotton Research and Development 21: 103-105.

Godfrey LD, Goodell PB, Natwick ET, Haviland DR, Barlow VM (2008) Cotton Leafhoppers.UC IPM Pest Management Guidelines: Cotton. Publication 3444. University of California, Davis.

Gopal D, Tarikul I (2014) Relative efficacy of some newer insecticides on the mortality of jassid and white fly in brinjal. International Journal of Research in Biological Sciences 4: 89-93.
Koffi AA, Darriet F, N'Guessan R, Doannio JMC, Carnevale P (1998) Evaluation au laboratoire de l'efficacité insecticide de l'alpha-cyperméthrine sur les populations d'Anophelesgambiae de Côte d'Ivoire résistantes à la perméthrine et à la deltaméthrine. Bulletin de la Société de Pathologie Exotique 92 :62-66.

Koffi SY (2013) Libéralisation de la filière coton en Côte d'Ivoire quinze ans après : empreinte spatiale et organisationnelle. Cinq Continents $3: 5-17$.

Koné PWE, Ochou GEC, Didi GJR, Dekoula SC, Kouakou M, Bini KKN, Mamadou D, Ochou OG (2017) Evolution spatiale et temporelle des dégâts du jasside Jacobiella facialis Jacobi, 1912 (Cicadellidae) en comparaison avec la distribution de la pluviométrie au cours des vingt dernières années dans les zones de culture cotonnière en Côte d'Ivoire. International Journal of Biological and Chemical Sciences 11: 1190-1201. DOI :https://dx.doi.org/10.4314/ijbcs.v11i3.21.

Kostic M, Stankovic S, Kuzevski J (2015) Role of AChE in Colorado Potato Beetle (Leptinotarsa decemlineata Say) Resistance to Carbamates and Organophosphates. Insecticides Resistance Stanislav Trdan, IntechOpen, Croatia Pp. 19-40. DOI: http://dx.doi/10.5772/61460.

Kundoo AA, Dar SA, Mushtaq M, Bashir Z, Dar MS, Gul S, Ali MT, Gulzar S (2018) Role of neonicotinoids in insect pest management: A review. Journal of Entomology and Zoology Studies 6: 333-339.

Lamotte E, Fleury D (2012) Effets de six insecticides sur Neoseiulus fallacis, un acarien prédateur des vignobles au Canada. Revue suisse Viticulture, Arboriculture, Horticulture 44 : 244-248.

Madar H, Katti P (2010) Incidence and diversity of leafhoppers on sunflower. Karnataka Journal of Agricultural Sciences 23: 149-150.

Martin T, Ochou GO, Djihinto A, Traoré D, Togola M, Vassal JM, Vaissayre M, Fournier D (2005) Controlling an insecticideresistant bollworm in West Africa. Agriculture, Ecosystems \& Environment 107: 409-411. DOI: https://doi.org/10.1016/j.agee.2004.11.006.

Martin T, Ochou GO, Hala NF, Vassal JM, Vaissayre M (2000) Pyrethroïd resistance in the cotton bollworm, Helicoverpa armigera (Hübner), in West Africa. Pest Management Science 56: 549-554.

Ochou GO, Martin T (2002) Pyrethroïd Resistance in Helicoverpa armigera (Hübner): recent developments and prospects for its management in Côte d'Ivoire, West Africa. Resistant Pest Management Newsletter 12: 10-16. 
Ochou OG (2011) Guide pour les traitements sur seuil du cotonnier en Côte d'Ivoire. Pasco-Ivoire, Abidjan.

Selvaraj S, Adiroubane D, Ramesh V (2011) Population dynamics of leafhopper Amrasca devastans Distant in cotton and its relationship with weather parameters. Journal of Entomology 8: 476-483. DOI: http://dx.doi.org/10.3923/je.2011.476.483.

Tomizawa M, Casida JE (2005) Neonicotinoid insecticide toxicology: mechanisms of selective action. Annual Review of Pharmacology and Toxicology 45: 247-68. DOI: 10.1146/annurev.pharmtox.45.120403.095930.

Vaissayre M, Cauquil J, Silvie P (1995) Protection phytosanitaire du cotonnier: Méthodes et moyens de lutte intégrée contre les ravageurs. Agriculture et Développement $8: 4-23$.

Wei Q, Yu HY, Niu CD, Yao R, Wu SF, Chen Z, Gao CF (2015) Comparison of insecticide susceptibilities of Empoasca vitis (Hemiptera: Cicadellidae) from three main tea-growing regions in China. Journal of Economic Entomology108: 1-9. DOI: 10.1093/jee/tov063. 